Scheller D`angelo, André, Lugo Quiroz, Edwin de Jesús,

"Conceptualización del Crimen Organizado y

su regulación en la legislación Penal Colombiana", Nuevo Foro Penal, 92, (2019)

\title{
Conceptualización del Crimen Organizado y su regulación en la legislación Penal Colombiana
}

\section{Conceptualization of Organized Crime and its regulation in Colombian Criminal Legislation}

\author{
André Scheller D'Angelo** \\ EdWIn de Jesús Lugo Quiroz ${ }^{* * *}$
}

Fecha de Recepción: 01/02/2019 - Fecha de aceptación: 13/05/2019

DOI: 10.17230/nfp.15.92.7

\section{Resumen}

El Crimen organizado, como fenómeno actual, ha sido estudiado no solo en cada país que lo padece, sino también por legislaciones internaciones, permitiendo esbozar un concepto adaptable a la realidad social de cada nación. Para Colombia, la construcción de ese concepto no ha sido una tarea sencilla, ya sea por descuido del órgano legislativo o por los problemas propios que enfrenta la construcción conceptual del crimen organizado (la pluralidad y la autoría, la permanencia en el tiempo, entre otros) como veremos a continuación.

* $\quad$ Este artículo hace parte de los resultados del proyecto DER2016-79705-R.

** Abogado de la Universidad Católica de Colombia, especialista y magister en Derecho Penal, Doctor en Derecho penal por la Universidad de Salamanca. Director del Departamento de Derecho Penal de la Universidad Sergio Arboleda sede Santa Marta. Docente investigador de la misma universidad. Docente catedrático de Procedimiento Penal y teorías penales de la Universidad del Magdalena. Conjuez de la Sala Penal del Tribunal Superior del Magdalena, Coordinador académico de la defensoría del pueblo regional Magdalena.

*** Abogado de la Universidad Sergio Arboleda, especialista en Derecho penal de la Universidad Sergio Arboleda y en Crimen organizado, corrupción y terrorismo de la Universidad de Salamanca. Candidato a Magister en Derecho de la Universidad Sergio Arboleda, Catedrático de la Universidad Sergio Arboleda en Derecho penal y docente de la Universidad Cooperativa de Colombia. 


\section{Abstract}

Organized Crime, as a current phenomenon, has been studied not only in each country that suffers these crimes, but also by international laws, which allow us to outline a concept adaptable to the social reality of each nation. For Colombia, the construction of this concept has not been an easy task, either due to the negligence of the legislative body or because of the problems inherent to the conceptual construction of organized crime (plurality and authorship, permanence in time, among others) as we will see below.

\section{Palabras Claves}

Crimen organizado, autoría, pluralidad determinada, temporalidad, voluntariedad, finalidad delictiva común, ley colombiana

\section{Key Words}

Crime organized, plurality, authorship, Colombian law

\section{Sumario}

1. Introducción; 2. El Crimen Organizado: un reto conceptual; 3. Organizaciones criminales en la historia de la humanidad; 4. Hacia una concepción de crimen organizado a partir de los tópicos hallados; $\mathbf{5}$. Latinoamérica y Crimen Organizado; $\mathbf{6}$. La realidad en Colombia. ONU y Crimen Organizado; 7. El silencio de la ley colombiana en la definición del crimen organizado; 8. Conclusiones; Bibliografía.

\section{Introducción}

La Convención de las Naciones Unidas contra la Delincuencia Organizada y Transnacional, también conocida como Convención de Palermo, por su firma en diciembre de 2000 en dicha ciudad, adoptada así mismo por las Naciones Unidas el 15 de noviembre de 2000, propone para los países firmantes de la misma, una manera de erradicación y lucha contra el crimen organizado a partir de la definición del mismo, dotando a esta modalidad delictual de características esenciales.

Así las cosas, lo aquí mencionado como crimen organizado, el órgano internacional lo ha denominado grupo delictivo organizado, el cual para que pueda llamarse como tal debe cumplir con unos elementos que bien se podrían agrupar en cuatro clases: pluralidad determinada; temporalidad; voluntariedad y finalidad delictiva común. 
El Reino de España, como Estado parte de la ONU, ratificó la Convención de Palermo, mediante documento suscrito por el Rey Juan Carlos I, el 21 de febrero de $2003^{1}$ y a partir del 29 de septiembre de 2003 entró en vigor la misma en todo el territorio. Así mismo a través de la Ley 800 del 13 de marzo de 2003, se aprueba por parte del órgano legislativo Colombiano la mencionada Convención internacional, de lo cual, posteriormente la Corte Constitucional, ejerciendo control de constitucionalidad (del que habla el artículo 241 numeral 10 de la Constitución Política nacional) declara exequible el instrumento internacional, mediante sentencia radicada C-962 del 21 de Octubre de 2003, validando así la actuación internacional de Colombia como Estado parte, en la firma de la Convención de las Naciones Unidas contra la Delincuencia Organizada y Transnacional.

Consecuente con lo anterior y teniendo presente la finalidad de la mencionada Convención: "(...) promover la cooperación para prevenir y combatir más eficazmente la delincuencia organizada transnacional". Se tiene, que tanto el Estado español como el colombiano, propenderían entonces por la erradicación del crimen organizado, adoptando medidas político criminales tanto preventivas como represivas para disminuir los índices de criminalidad organizada.

Así mismo, cumpliendo con este propósito, Colombia ha aumentado las penas y ampliado el campo de acción del delito de concierto para delinquir, siendo este el tipo penal que castiga el actuar de una organización criminal, e incluso, el legislador ha ampliado el campo de aplicación del mismo delito, agravando las penas cuando esa agrupación criminal verse sobre la comisión de otros punibles determinados, concretamente se ha visto con la Ley 1121 del 2006 y Ley 1762 de 2015.

Sin embargo, teniendo en cuenta lo establecido en el Convenio en mención, existen ciertas disparidades en la tipificación objetiva, del mencionado delito en la legislación penal colombiana. Se examinará entonces, la viabilidad de la estructura típica objetiva del delito de organización criminal en la legislación española frente a lo establecido por el legislador penal colombiano en el artículo 340 de la ley 599 del 2000 (conocido como Código Penal Colombiano); teniendo como referente la Convención de Palermo como parámetro legal internacional.

1 Instrumento de Ratificación de la Convención de las Naciones Unidas contra la Delincuencia Organizada Transnacional, hecho en Nueva York el 15 de noviembre de 2000. Agencia Estatal Boletín Oficial del Estado. https://www.boe.es/buscar/doc.php?id=BOE-A-2003-18040. Consultado 30/06/2016. 
Dicho esto, se realiza el presente artículo como resultado del proyecto de investigación DER2016-79705-R, guiados bajo un método analítico deductivo, con enfoque cualitativo, se abordó el objetivo general de la investigación: determinar si existe tipificación objetiva de la delincuencia organizada, en el ordenamiento jurídico colombiano.

De este modo, se permitió indagar en la doctrina nacional e internacional al respecto, así como en instrumentos normativos de organismos internacionales, haciendo uso para ello de fichas de análisis documental, partiendo de los retos conceptuales que plantea la construcción del concepto de delincuencia organizada, basado en las realidades criminológicas contemporáneas; seguido de ello se muestra una perspectiva histórica de este comportamiento delincuencial, con la finalidad de determinar tópicos comunes en cada suceso histórico y construir un concepto autónomo de este fenómeno.

Para finalizar se analizan las legislaciones internacionales, si abordan o no el concepto de delincuencia organizada y cual es la consecuencia que para ello se plantea, por ultimo y aterrizando en nuestro contexto, se determina cual es el abordaje que el legislador colombiano hace a la delincuencia organizada y cual es la prohibición que internamente se establece, todo ello a partir del análisis crítico de la ley y algunos instrumentos jurisprudenciales.

\section{El Crimen Organizado: un reto conceptual}

Si bien se parte del concepto otorgado por la Convención del Palermo en su artículo segundo respecto de lo que se conoce como grupo delictivo organizado, debe estudiarse doctrinalmente lo que se entiende como el fenómeno de "organización criminal", apuntando a definiciones elaboradas tanto en Europa, como en Colombia. De este modo, se encuentra que el concepto de criminalidad organizada, es amplio, para algunos autores muy impreciso y lleno de relativismos, lo que conlleva en algunos casos a problemas de interpretación en las instancias judiciales². Tal dificultad conceptual, según Zúniga Rodríguez, radica en la disparidad existente entre tantos territorios y sistemas políticos, dado que en cada sociedad el imaginario colectivo, representará el término "criminalidad organizada" en diferentes fenómenos, o dicho de otra manera, no todas las naciones padecen de los mismos problemas de

2 Choclán Montalvo, José Antonio. La organización criminal, tratamiento penal y procesal, Madrid, Dykinson, 2000. 
criminalidad organizada, por lo cual no tienen un concepto homogéneo. ${ }^{3}$

En Colombia, por ejemplo, el concepto de crimen organizado, según se ha esbozado por algunos tratadistas internacionales, puede observarse mayoritariamente desde dos delitos: el tráfico de drogas ilícitas y el terrorismo. Sin embargo, en la realidad criminológica colombiana, existen otras conductas típicas que se ejecutan por individuos agrupados de manera organizada y sistemática con una finalidad delictiva común, ejecutando así conductas como extorsión, estafa, trata de personas, entre otros.

De lo anteriormente mencionado, según la Revista Jurídica Colombiana, Ámbito Jurídico, en su editorial de marzo de 2015, se explica que, para ese año según informes de la Fiscalía General de la Nación colombiana, el órgano de persecución, identificó 1.200 organizaciones criminales, las cuales superan los 3500 integrantes; dedicadas no solo al narcotráfico y extorsión, sino también a otros delitos en forma conexa, propios de la delincuencia común. Estas organizaciones criminales, según lo esbozó el entonces Fiscal General de la nación, Eduardo Montealegre Lynett, se desarticularían en su estructura atacando su fuente de financiación. ${ }^{4}$

Amén de lo anterior, el periódico El Tiempo (colombiano), en publicación del 21 de abril de $2016^{5}$, ha publicado informe por parte del presidente de la República de entonces Juan Manuel Santos Calderón, respecto de la lucha contra una nueva modalidad de criminalidad organizada en ciertos departamentos de Colombia (Antioquia y Chocó en su mayoría): la minería ilegal. Esta modalidad delictiva en Colombia, se refiere a la explotación de recursos minerales (en su mayoría de metales preciosos -oro y mercurio-) dentro del territorio, sin el lleno de los requisitos legales (medidas administrativas, contractuales y seguridad industrial), a manos de particulares. Causando así un grave impacto ambiental y con una utilización indebida de los espacios naturales nacionales. Arrojando una cifra (para julio del 2015) de 8.202 personas capturadas, cifra dada a conocer por la Presidencia de la República. El problema de la minería ilegal, va más allá del impacto ambiental, también, según lo dejó publicado el Ministerio de Minas y Energía (julio 2015), citando al

3 Zúñiga Rodriguez, Laura. Criminalidad organizada y sistema de derecho penal, Granada, Comares, 2009.

4 Extraído de http://www.ambitojuridico.com/BancoConocimiento/Laboral-y-Seguridad-Social/fiscaliaanuncia-politica-de-estado-para-la-lucha-contra-las-bandas-criminales. Consultado el 21 de julio de 2016.

5 Las publicaciones de prensa que se referencias son respaldadas por informes de los distintos Ministerios de la República de Colombia, lo anterior con la finalidad de ratificar la información suministrada por los medios de comunicación. 
supremo mandatario, en cuanto a seguridad pública (sin desconocer la vulneración al medio ambiente como bien jurídico), la consecuencia negativa se centra en que la minería ilegal, particularmente la explotación del oro, paulatinamente ha venido reemplazando al narcotráfico como crimen organizado, fuente de financiación al terrorismo y los ingresos ilícitos ascienden a 7.1 billones de pesos anuales.

Lo anterior, sin mencionar el trabajo infantil y los desplazamientos forzados ${ }^{6}$ que ésta práctica organizada ilegal causa a las comunidades vecinas de los yacimientos de oro y mercurio. Otra situación que moderniza (en el caso colombiano) el concepto de criminalidad organizada o bien, la actividad criminal a la que podría dedicarse la organización, es el contexto ambiental (ya no social y cultural, como es el caso del narcotráfico y la extorsión o la minería ilegal, que tiene su fuente de origen en la escasez de empleabilidad formal) y ecológico en el que se mueve la organización.

Así las cosas, el tráfico de especies silvestres, se ha convertido en Colombia también en una de las actividades delictivas preferidas por las organizaciones criminales. La razón de lo anterior, son las grandes utilidades que esta explotación ambiental representa como negocio, sus réditos oscilan entre 6.000 y 10.000 millones de dólares anuales ${ }^{7}$ y aunado a ello, la facilidad del producto objeto de comercio: Colombia es un país diverso, que ocupa el $10 \%$ de la fauna y flora mundiales, en tan solo $0,7 \%$ del territorio del planeta. ${ }^{8}$ Tales situaciones conllevan a que dentro del país se reestructure el concepto de crimen organizado y varíe con la perspectiva tradicionalista internacional, frente a delitos como terrorismo y narcotráfico, lo cual dificulta en alguna manera proporcionar el concepto de crimen organizado.

Se observa por tanto, que plantear un concepto universal y valido de criminalidad organizada, no es tarea sencilla, puesto que de un lado están los fenómenos sociales que padece cada territorio y por otro los parámetros legales sobre los que se rige (los cuales de algún modo son el eje central de este artículo). Sin embargo, el concepto de crimen organizado como lo ha dicho Zúñiga Rodríguez es necesario por cuatro razones esenciales: en primer lugar, para lograr la determinación de los objetos de protección y las formas de ataque; en segundo lugar, es necesario para distinguir la criminalidad organizada de otros tipos de criminalidad, como el

6 Según informe presentado por la Unidad de Victimas (organismo del Estado Colombiano, constituido en 2012, creada con la finalidad de "Liderar acciones del Estado y la sociedad para atender y reparar integralmente a las víctimas, para contribuir a la inclusión social y a la paz").

7 Hernández, Chávez y otros, International Crime Threat Assessment, 2000.

8 Hernandez Chavéz, Mabel , y Jorge Linares Hamann. "Tráfico de especies silvestres como empresa del crimen organizado", en Revista Criminalidad, Lo local y el Crimen Organizado, 2006, pp. 338-348. 
narcotráfico, terrorismo, entre otros, lo cual, igualmente construir su definición no fue sencilla; tercero, por la evolución globalizada que dicha forma delictiva, a tal punto de lograr la atención de organismos internacionales; y por último, si lo que se desea es la erradicación de la misma o bien la minimización de sus efectos (o ambas), es necesario conocer qué se entiende por criminalidad organizada. ${ }^{9}$

Así mismo como lo ha dicho Medina Ariza, citado por Zúñiga, la importancia de la definición de crimen organizado, resulta esencial por cuanto al no saberla, no podríamos prevenirlo, ni combatirlo, dado que no sabemos a qué nos estamos enfrentando realmente. ${ }^{10}$ El derecho penal, sin embargo, aunque sea conocido como una ciencia integrada, toda vez que abarca un número plural de disciplinas que lo hacen integral y uniforme ${ }^{11}$; no ha ofrecido una respuesta clara respecto del concepto de criminalidad organizada.

Lo anterior, según asegura Zúñiga, se debe a fundamentalmente tres razones, las cuales podemos sintetizar de la siguiente manera: primera, el concepto empírico criminológico tradicional del crimen organizado; toda vez que se ha abandonado las bases científicas del derecho penal para definir el concepto de criminalidad organizada y se ha cimentado en bases empíricas de índole criminológicas, haciendo difícil la tarea, de reestructurar esas nociones sobre las bases del derecho penal. ${ }^{12}$ No con ello, estamos deslegitimando la importancia de la criminología en el saber de las ciencias penales, y la definición de conceptos como el que se encuentra en estudio, sino que, bien ha definido Velásquez Velásquez la criminología, como el conjunto ordenado de saberes empíricos del delito, del delincuente y sobre los controles de esa conducta, en ese entendido, se alude a una parcela del conocimiento; que como podemos establecer, es distinta a la ciencia penal integrada. ${ }^{13}$

La criminología, puede ser más acertada o brindarnos una concepción teórica más próxima al crimen organizado, dado que el objeto de estudio de la misma es aún más amplio que el de la dogmática penal, extendiéndose a realidades un poco

9 Zúñiga Rodriguez, Laura. Criminalidad organizada y sistema de derecho penal, Granada, Comares, 2009.

10 Ibídem

11 Velásouez Velásouez, Fernando. Manual de derecho penal parte general, Bogotá, Andres Morales, 2014.

12 Zúñiga Rodriguez, Laura. Criminalidad organizada y sistema de derecho penal, Granada, Comares, 2009.

13 Velásouez Velásouez, Fernando. Manual de derecho penal parte general, Bogotá, Andres Morales, 2014; p. 19 
desconocidas para el mismo. El delito, el delincuente, la víctima, la criminalidad y el control social, son los tópicos del objeto de estudio de la criminología ${ }^{14}$, lo cual permite extenderse a otros aspectos más allá de la norma misma propia del derecho penal.

De lo dicho, se debe afirmar que las definiciones legales, delimitan artificialmente y de una manera poco provechosa, que no puede condicionar la autónoma definición de las ciencias sociales, citando a Baratta ${ }^{15}$ por Zúñiga Rodríguez. ${ }^{16}$ En segundo lugar, respecto de las complejidades destacadas por la doctrinante, se ubica la heterogeneidad y variabilidad de la noción de criminalidad organizada, incompatibles con los paradigmas de la norma penal, esto es, que no existe un punto común 0 una base sólida desde el concepto de la norma penal que permita definir interculturalmente la criminalidad organizada.

Por último, por la problemática de autoría colectiva que esta definición sugiere, lo cual quiere decir, que la criminalidad organizada plantea una situación paradójica frente a las construcciones teóricas de autoría tratadas en el derecho penal (el autor, visto desde un comportamiento individual), puesto que esta supone el comportamiento "grupal de autoría", generando un ataque organizado a los bienes jurídicos. La organización, como forma de autoría, supone un desafío para la norma penal, puesto que denota una contrariedad a la responsabilidad individual propia del derecho penal. Sin embargo, con ello no se está desconociendo las formas de coautoría y participación, dentro de la organización delictiva. Lo que se plantea es la visión de organización, no como el mero término, sino como una categoría compleja de la criminalidad, debido que, esta considera el análisis de lo múltiple, multifactorial y contextual. ${ }^{17}$

Ahora bien, podría decirse que de igual forma el derecho penal plantea, formas de autoría que sugieren la participación colectiva de individuos con un fin delictivo determinado.

Sin embargo, bien lo ha dicho ${ }^{18}$, en cuanto no puede equipararse el concepto de mera coautoría, dado que ésta sencillamente exige una pluralidad de personas que se distribuyen funcionalmente los respectivos cometidos, mientras que la organización

\footnotetext{
14 Ibídem

15 Baratt. s.f.

16 Zúñiga Rodriguez, Laura. Criminalidad organizada y sistema de derecho penal, Granada, Comares, 2009.

17 Ibídem

18 Choclán Montalvo, José Antonio. La organización criminal, tratamiento penal y procesal, Madrid, Dykinson, 2000.
} 
criminal, según el autor, denota una mayor intensidad de la voluntad criminal, teniendo en cuenta los siguientes aspectos: la planificación previa de la operación criminal, detallando previamente su alcance y las funciones de quienes intervienen, determinando así una figura jerarquizada, la cual adquiere cierta autonomía respecto de los individuos que contribuyen a la consumación del objeto de esa empresa u organización criminal. Concretamente, en cuanto a la situación de la autoría en la criminalidad organizada (y con ello la imposibilidad de su definición), la problemática se centra en cómo establecer qué conductas pueden ser consideradas, a quienes y en qué grado, se debe exigir responsabilidad penal por sus comportamientos, en referencia a la actividad grupal. ${ }^{19}$

De acuerdo con la doctrina tradicional del dominio del hecho, el derecho penal, se ha encargado en la responsabilidad penal del "jefe de la organización jerárquica" por los delitos cometidos por sus subordinados, para resolver la nebulosa idea de la autoría y participación en los supuestos de criminalidad organizada, según Roxin.

Sin embargo, acorde a lo dicho por Zúñiga Rodríguez, no siempre, en los casos de criminalidad organizada, nos encontramos ante organizaciones jerárquicas, atacando entonces la idea de la existencia de un aparente "jefe". Vemos entonces la complejidad de la autoría en la organización criminal, distando de los conceptos propios de autoría contemplados por el derecho penal a partir del estudio de la norma. No resulta entonces una tarea fácil para el derecho penal, desde esa perspectiva y las anteriormente mencionadas, aportar una definición de criminalidad organizada. El problema de la conceptualización del crimen organizado, según lo afirma Choclán Montalvo, plantea problemas de legalidad e interpretaciones por parte de los tribunales, en cuanto a la exigencia de determinación de los tipos penales, puesto que la organización puede presentarse con alcances en distintos niveles, ya sea nacional o supranacional, e incluso puede tener por objeto una 0 varias actividades delictivas, situación que impide aportar concepto totalitario y completamente delimitado de criminalidad organizada. ${ }^{20}$

Ahora bien, resulta imperioso preguntarse, a raíz de los planteamientos suscitados ino es posible entonces, construir un concepto univoco y exacto de criminalidad organizada?, pues bien, para responder a esta pregunta, ya habiendo

19 Zuñiga Rodriguez, Laura. Criminalidad de empresa y criminalidad organizada, Lima, Jurista, 2013.

20 Choclán Montalvo, José Antonio. La organización criminal, tratamiento penal y procesal, Madrid, Dykinson, 2000; p.7. 
sopesado los obstáculos que se avienen al definir el crimen organizado desde el derecho penal y proporcionar una concepción universalmente valida del mismo, debe acudirse a la historia y hacer un recorrido por la misma.

\section{Organizaciones criminales en la historia de la humanidad}

A continuación que se citarán dos momentos significativos en la historia de las civilizaciones occidentales y que, sin duda, marcaron un precedente en la génesis de la criminalidad organizada y así mismo, a raíz de ellas, a la creación de políticas de estado e internacionales para prevenir y desarticular el crimen organizado. Afirma Rivera Clavería que:

La criminalidad es tan vieja como la historia de la humanidad, desde los contrabandistas y el negocio ilícito de la seguridad y protección en la antigua Roma, pasando por todo el entramado de las estructuras que florecieron con la piratería en el siglo XVII. ${ }^{21}$

\section{La colonización de Roma}

Lo anterior se puede sustentar con la simple observancia de las leyendas romanas que dan cuenta del origen de la ciudad, donde según parece existieron conspiraciones y organizaciones delictivas que dan cuenta de la existencia de una pluralidad de personas, organizadas sistemáticamente y con una finalidad delictiva común. Con esto se hace referencia a la leyenda conocida como "El rapto de las sabinas" y posterior a ella "la traición de Tarpeya"22 La historia del rapto, cuenta que valiéndose de argucias y una fachada aparentemente inofensiva, los latinos, liderados por el fundador de Roma: Rómulo, crearon una fiesta para atraer a los miembros de la comunidad vecina: los latinos y así mismo raptar a sus mujeres para poblar la naciente Roma. Dicho plan se llevó a cabo conforme se tenía previsto y permitió la población de la ciudad.

Los romanos de la historia contada, fraguaron una idea criminal perfectamente estructurada para ejecutar una aparente "trata de personas", sin embargo, si bien tiene ciertos elementos de la criminalidad organizada, no puede ser considerada

21 Rivera Clavería, Julio. "Galile/o.edu", enero de 2011. http://www.galileo.edu/ies/files/2011/04/EL CRIMEN_ORGANIZADO-IES.pdf; p.3.

22 Extraído de: http://www.historia-roma.com/02-rapto-sabinas.php, consultado el 9 de septiembre de 2016. 
propiamente como tal, puesto que según lo ha afirmado Zúñiga Rodríguez ${ }^{23}$, las conspiraciones, la clandestinidad de ciertos grupos y disidencia de los mismos, siempre han existido en la historia, sin embargo, estas no están cimentadas en una estructura de tipo empresarial, es decir, donde su existencia depende del mercado ilícito, exigiendo en consecuencia, que la criminalidad sea propia de las sociedades de mercado. Vemos entonces, que conforme a los sucesos que nos ofrece la historia antigua, no cualquiera pluralidad de personas, delinquiendo de manera organizada, pueden considerarse como criminalidad organizada.

\section{Piratas, corsarios y bucaneros: génesis del crimen organizado marítimo}

El auge de la piratería tuvo lugar entre los siglos XVI y XVII, concentrando su dominio en el mar mediterráneo, consistiendo esta en atracar en una zona determinada y apoderarse a través de la violencia de las riquezas (constituyéndose en el "botín", siendo este el ingreso o utilidad ilícita de la organización) de ese territorio. Los piratas, no solo se apoderaban de riquezas provenientes de tierra firme, sino también de otras embarcaciones durante su navegación en alta mar, tomando (incluso) prisioneros a los miembros de la tripulación de dichas embarcaciones o el mercado de esclavos.

La piratería llegó a convertirse en un negocio tan lucrativo que logró corromper a u nuestros aborígenes y los llevó incluso, a formar parte de esta organización delictiva:

Dándose cuenta de que la piratería constituía tanto una rama del comercio como de la navegación, pusieron en práctica un sistema inteligente que les aseguraba, mediante el pago de la presa (en general el $10 \%$ del botín) a los jefes indígenas de la costa, una protección para sí mismos y salidas para sus mercancías. A cambio de estos pagos, el jeque se comprometía a proteger a sus socios contra cualquier enemigo y a poner a su disposición un mercado libre para el producto de sus expediciones. ${ }^{24}$

Uno de los corsarios de mayor significancia en la historia de la piratería, fue el apodado Capitán Barbarroja, quien según se cuenta, tuvo su primera aparición en 1504, atacando una de las galeras papales (Papa Julio II) en las costas del Mar tirreno. Este pirata, fue conocido por la barbarie con la cual penetraba junto con su

23 Zúñiga Rodriguez, Laura. Criminalidad organizada y sistema de derecho penal, Granada, Comares, 2009; p.599.

24 Gosse, Philı. Historia de la pirateria, Febrero de 2013. https://doscenturiasymasalla.files.wordpress. com/2013/02/32730422-philip-gosse-historia-de-la-pirateria.pdf; p.9. 
tripulación, en las costas y las embarcaciones. La piratería, según aprobó el Consejo de la Corona Británica en 1873, teniendo como base la definición dada en Rex V. Dauson en 1696, se consideró como:

La piratería no constituye sino un término marítimo que define el robo a mano armada en el dominio de la jurisdicción del Almirantazgo... Cuando el marino de un barco despoja por la violencia al patrón y luego desplaza el navío o cargamento del mismo con intención criminal y esto dentro de la zona circunscrita por la jurisdicción del lord almirante, entonces se trata de robo a mano armada y de piratería. ${ }^{25}$

Colombia (entonces conocida como el Virreinato de Nueva Granada -período comprendido entre 1550 y 1717- por encontrarse bajo el dominio de la Corona Española), también fue víctima de ataques por parte de los barbáricos corsarios y ello era apenas lógico: era uno de los pocos territorios de la antigua América, que contaba con doble vía de acceso marítimo: océano Pacífico y océano Atlántico, eso sin mencionar la riqueza mineral y esclavista que ella albergaba. La provincia de Santa Marta (Hoy Santa Marta- la ciudad más antigua de Suramérica, fundada en 1525-) fue fuertemente atacada por parte de estos "grupos criminales", dejando como consecuencia las destrucciones de la ciudad, quemas y constantes saqueos de la misma. ${ }^{26}$

Según afirma el historiador samario Arturo Bermúdez Bermúdez, en su obra histórica Piratas en Santa Marta (1993), Santa Marta fue saqueada y quemada 19 veces por corsarios, entre los años de 1655 y 1692, es decir durante 37 años, donde en más de una ocasión quien atacaba era la misma flota pirata varias veces, ejemplo de ello encontramos al pirata y comerciante inglés John Hwakins (cuyas invasiones constantes se prolongaron en toda la provincia de Santa Marta - que comprendía lo que hoy se conoce como Guajira y Cesár- desde 1565 hasta 1595 -donde fallece abatido en su última expedición) y Sir Francis Drake, de la misma nacionalidad (cuyas invasiones fueron repetitivas entre 1568 y 1595). ${ }^{27}$

Según Bermúdez, estos piratas, en las antiguas costas colombianas, buscaban ingresar a las provincias con los siguientes fines: abastecerse, traficar con esclavos, obligar al comercio con los vecinos de la Provincia y las autoridades, saquear la ciudad y consecuentemente destruirla. Estos asechadores marítimos, como mencionamos

25 Ibídem p.124.

26 Bermudez Bermudez, Arturo. Piratas En Santa Marta, Santa Marta, Kimpres, 1991.

27 Ibídem 
anteriormente, no actuaban solos, todo lo contrario, si bien eran comandados por un capitán (que son los mencionados como piratas anteriormente), existía una pluralidad de agentes que realizaban todas las labores barbáricas y desarrollaban el cometido criminal de propia mano.

Cabe decir que igualmente (como dentro de toda embarcación) existía delegación de funciones y organización de las mismas, así por ejemplo encontramos que en el ataque de Hwakins a la entonces población de Rio de Hacha (hoy ciudad de Riohacha y que para la época que data, ese territorio hacía parte de la provincia de Santa Marta), en 1565, envió previamente a uno de sus soldados (según la historia data, llamado: Juanes) a "pedir permiso a los señores del cabildo para vender esclavos y otra mercancía que traía"28, de tal suerte que si el cabildo no aceptaba, echaría a tierra entre 200 y 300 hombres para que asolaran el pueblo, lo cual efectivamente sucedió. Nueva Granada, no fue el único territorio americano que padeció el flagelo de los piratas, también, toda la costa occidental de la "América Española", principalmente Santo Domingo, Jamaica y Cuba, entre otras.

Pero ¿Por qué era tan barbárica esta forma de criminalidad?, de ello debe decirse, que dado que los piratas al tomarse un territorio o una embarcación, tomaban un botín y de este mismo, se repartían las ganancias, era necesario el empleo de la violencia, toda vez que si no se hacía uso de la misma, no se conseguía el botín y por ende, no habría paga. ${ }^{29}$ Vemos que, el producto ilícito obtenido como consecuencia de la actividad criminal, era el sustento de los miembros de la organización y por así decirlo el capital que les permitía seguir en funcionamiento.

El recuento de este episodio fatídico, de la piratería nos ofrece otro elemento que indiscutiblemente se repite a lo largo de la historia y que podría ayudarnos a construir el concepto de organización criminal, y ello es la permanencia en el tiempo o bien, la duración de la misma organización. Analizando el comportamiento pirata, descrito anteriormente, logra observarse que los mismos, no actuaban individualmente (pluralidad de individuos en la comisión criminal), la finalidad de los miembros de la organización no era más que desarrollar actividades delictivas, para satisfacer sus necesidades económicas y darle continuidad al actuar delictivo (finalidad delictiva común) y que para hacer más fuerte la organización, dominando un determinado territorio o embarcación, era necesario penetrarla(0) varias veces, mediante violencia e intimidación, perpetuándose este territorio como fuente de ingresos delictivos para los mismos (elemento temporal de la organización).

28 Ibídem, p.57.

29 Ibídem 
La dominación territorial y el uso de la violencia, no eran más que medios para conseguir la utilidad ilícita, mientras que la organización grupal, era necesaria para desarrollar la actividad delictiva, así como la distribución funcional y jerarquizada (partiendo del Capitán del navío mayor-Barbarroja, Sir Francis Drake, etc), puesto que en ningún episodio de la historia consultado, se observó la conducta individual del capitán, sino por el contrario, mientras mayor número de embarcaciones y hombres comandara, mayor era el temor y reverencia que le debía la población sometida. Además, puede decirse que de igual forma, que el volumen de la tripulación que se comandaba, era directamente proporcional al "prestigio" o al reconocimiento que la organización alcanzaba dentro de los territorios, lo cual logra evidenciarse aun en la actualidad, pues continúa hablándose de las labores delictivas de los mismos, aseverándose que poco eran conocidos los piratas y corsarios con poca tripulación, pues sus ataques no eran muy numerosos y consecuentemente eran vencidos fácilmente.

Por otro lado, la internacionalización unida muchas veces al desarrollo tecnológico y a la criminalidad organizada, lleva a la existencia muy especialmente en el ámbito económico, pero no solo, de comportamientos delictivos que por su forma de comisión implican a varios Estados, son los delitos transfronterizos (Berdugo, 2018).

Concluyendo este acápite se encuentra que para concretar un concepto de criminalidad organizada deben tenerse en cuenta cuatro tópicos claves a saber: 1. la pluralidad de personas en la organización criminal, no cualquier pluralidad sino una verdaderamente estructurada; 2 . el propósito criminal común dentro de toda la organización, 3. la duración en el tiempo (concluido en párrafos anteriores) y sin duda, 4. la finalidad lucrativa, es decir, ese propósito criminal de la organización, tiene como ingrediente subjetivo lucrarse ilícitamente.

\section{Hacia una concepción de crimen organizado a partir de los tópicos hallados}

Según las conclusiones señaladas en el acápite anterior, puede notarse que la definición de criminalidad organizada, no se da a partir de un ¿Qué es? sino que, su concepto parte de ¿Cuáles son?, haciendo referencia a los tópicos que caracterizan este fenómeno. La doctrina ha establecido que las definiciones de criminalidad organizada, se centran en tres construcciones o problemáticas fundamentales: cuestionar las características del crimen organizado; enumerar las mismas o las fases o condiciones para que esta se presente, haciendo más complejo el proceso 
de aportar una definición propiamente. ${ }^{30}$

Coincidiendo con Zúñiga Rodríguez, resulta imperioso construir el concepto de criminalidad organizada a partir de tres componentes característicos fundamentales: la organización, la finalidad lucrativa y la comisión de delitos. ${ }^{31}$ Se añade, que pueden concurrir otros elementos que extienden la criminalidad organizada, y estos pueden ser la transnacionalidad, vinculación con el mundo empresarial, entre otros; sin embargo estos elementos como bien se estableció, extienden la definición y siendo agregados a las características esenciales y que el hecho de no definirlas 0 examinarlas no afectan el núcleo esencial. ${ }^{32}$

\section{La organización}

En cuanto al concepto de organización, debe partirse de la definición gramatical para entrañar su esencia, esto es, según la RAE, el concepto de organización, hace referencia a una asociación de personas regulada por un conjunto de normas en función de determinados fines ${ }^{33}$. Dicha definición da cuenta de la exigencia para que surja la organización socialmente hablando: la pluralidad de voluntades. Aun, no hemos establecido cuanto es el mínimo de esa pluralidad, sin embargo es importante destacar que ha de suponerse que no puede ser un número reducido.

La organización, (partiendo aun de la base lingüística señalada, pero adentrándonos más al fenómeno social) exige además una estructura, que perfeccione 0 haga posible la consecución de la finalidad. ${ }^{34}$ Dado que debe preservarse la organización en aras de conseguir una finalidad ilícita, debe entenderse entonces que los "organizados" deben gozar de cierta estabilidad en la organización, para solidificarla. La estructura de la organización supone también, además de la estabilidad, un reparto de funciones o roles, sea cual sea la asignada, debe ir encaminada a la finalidad criminal. Ese reparto, demanda una orientación jerárquica en las funciones u horizontal, sea cual sea la orientación, es requisito, como se dijo, el reparto de esos roles o funciones dentro de la organización. Según lo ha señalado la doctrina, existen diferentes formas estructurales de la organización, las cuales, no

30 Fabián Sain, Marcelo, y Nicolas Rodríguez Games. Tendencias y desafíos del crimen organizado en latinoamerica, Buenos Aires, Universidad Metropolitana para la Educación y el Trabajo UMET, 2015.

31 ZuñIga Rodriguez, Laura. Criminalidad de empresa y criminalidad organizada, Lima, Jurista, 2013; p.611.

32 Ibídem

33 Extraído de http://dle.rae.es/?id=RBkqiJl. Consultado el 8/09/16.

34 Zuñiga Rodriguez, Laura. Criminalidad de empresa y criminalidad organizada, Lima, Jurista, 2013 
variarán el concepto como tal de organización, pero si los medios y la aproximación a la finalidad delictiva. ${ }^{35}$ Entre dichas variedades estructurales, encontramos: la jerárquica o piramidal (es la más común); estructura horizontal, celular o red y por último la estructura fluida.

La primera estructura, exige de sus integrantes un orden de superioridad entre ellos, ya sea marcado por el profesionalismo en la actividad delictiva, la edad, consanguinidad o incluso por la vocación o liderazgo que alguno 0 algunos de ellos ostenta como cualidad. Se considera que este tipo de estructura organizacional alberga la mayor peligrosidad, toda vez que por su perfección jerárquica requieren una mayor capacidad operativa y estratégica a la hora de ejecutar el crimen.

De acuerdo con el Consejo de Europa de 1999, respecto de la situación atinente al crimen organizado en Europa, se considera, que la jerarquía en este tipo de estructuras, está representada en tres niveles. El primer nivel: la dirección, en donde se toman las decisiones y por lo general no participan directamente en la comisión del delito, suelen ser profesionales en asuntos relacionados con la comisión de la conducta delictiva ${ }^{36}$. En segundo nivel, en el cual existe heterogeneidad en su composición, estos instruyen a los miembros ordinarios del grupo (propios del tercer nivel) y ocasionalmente participan en la comisión de conductas que guardan una relación teleológica con la finalidad ilícita de la organización, carecen de poder de decisión pero gozan de cierta autonomía en su comportamiento. ${ }^{37} Y$ por último, aquellos que cometen de propia mano el delito o los delitos (según sea), su cantidad es variable de acuerdo a las necesidades de la operación.

Sanchez García establece como ejemplo de las estructuras jerárquicas, las clásicas mafias italianas, jerarquizadas en razón de la consanguinidad o la experiencia de sus miembros ${ }^{38}$, con ello igualmente concuerda Povea Criado ${ }^{39}$, sin embargo este

35 Sanchez García, Isabel. Criminalidad organizada, aspectos penales, procesales, adminsitrativos y policiales, Madrid, Dykinson, 2005.

36 Así por ejemplo, si se tratare de una organización dedicada a la minería ilegal (como el caso colombiano, mencionado paginas atrás) la dirección estaría a cargo de algún o algunos individuos, con al menos conocimientos científicos en ingeniería de minas, química, geología, biología, entre otras áreas.

37 Comprende por ejemplo, a aquellos que desempeñan labores de "escoltas" o supervisores del material, dentro de la organización, cuando se trata de tráfico de sustancias psicotrópicas y alucinógenas.

38 Sanchez García, Isabel. Criminalidad organizada, aspectos penales, procesales, adminsitrativos y policiales, Madrid, Dykinson, 2005.

39 Poveda Criado, Miguel Angel. Terrorismo global y crimen organizado, Madrid, Fragua, 2015. 
hace alusión a otro tipo de mafias familiares: la mafia neoyorquina por ejemplo. Un dato importante y es que las mafias (hablando de la italiana y la neoyorquina) como grupos organizados, es extraña la jerarquización con heterogeneidad de sexos, sino por el contrario, en todas los niveles (sobre todo en el primero y segundo), se asientan individuos de igual sexo y género. Así lo ha confirmado Sanchez García, al establecer que es muy poco habitual la participación femenina en la organización criminal ${ }^{40}$, conforme a lo dicho en el "Report on the Organised Crime Situation in Council of Europa Member States, 1998", cit. Cap. II, Section 1.2. n." 17. (p.62).

Existe una sub clasificación de las estructuras organizadas del crimen, y es aquella consistente en manejar esa misma formación piramidal, pero esta vez de varios sub grupos en sí. Ejemplo de estos, son los "28s" la cual surgió en las prisiones de Sudáfrica, teniendo sub grupos jerarquizados como tal, pero todos ellos entrelazados, pues dependían de un dominio de cuatro personas, encargadas de preservar la disciplina y sus propios códigos. ${ }^{41}$

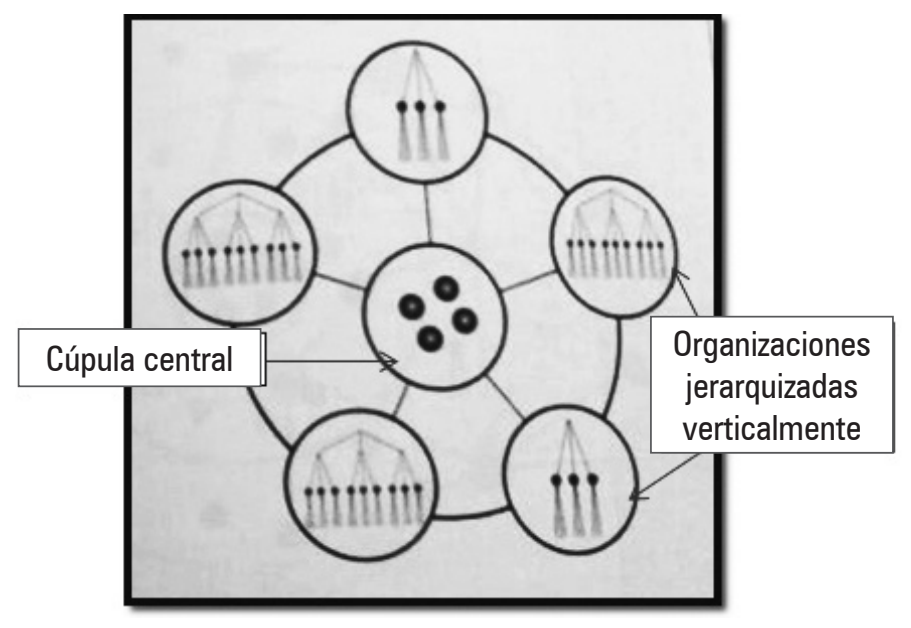

Tomado de (Poveda Criado, 2015, p.299)

La segunda estructura de organización: horizontal, celular o de red. Se refiere a aquellas organizaciones caracterizadas por su falta de coordinación, combatientes internamente entre sus integrantes, existiendo entre los mismos fuertes lazos de lealtad.

40 Sanchez García, Isabel. Criminalidad organizada, aspectos penales, procesales, adminsitrativos y policiales, Madrid, Dykinson, 2005.

41 Poveda Criado, Miguel Angel. Terrorismo global y crimen organizado, Madrid, Fragua, 2015; p.299. 
La tercera forma de estructura es la llamada, estructura fluida. Esta clase de organización, guarda mucha relación con la estructura de red o celular, pues son igualmente débiles y escazas de coordinación, sin embargo, se les denomina fluidos, toda vez que sus integrantes se reubican funcionalmente 0 se prescinde de ellos, organizándose y reorganizándose terminando la operación, esto con la finalidad, de disminuir el riesgo de ser capturados. ${ }^{42}$ Mientras mejor estructurada es la organización (en cualquiera de los enfoques proporcionados), alcanza mayor solidez y profesionalismo, y con esto complejidad para la investigación por parte de las autoridades en la desarticulación de las mismas. Tal situación se agrava aún más cuando, por ejemplo en modelos jerárquicos de organización (ya sean propiamente dichos 0 en racimos), la estructura es orientada por la edad y el parentesco, donde los hijos continúan la labor del padre y así sucesivamente.

De acuerdo a la afirmación anteriormente realizada, según considera Poveda Criado, la policía o en general, los miembros de fuerzas de seguridad del Estado (en el caso colombiano, la Policía y todas las Fuerzas Militares - armada, ejército, fuerza aérea-.), pueden capturar a algún o algunos miembros, pero no erradicar como tal la organización, solo limitar su poder hasta paulatinamente hacer cesar sus actividades (cuestión que puede tardar mucho tiempo), impidiendo acabar abruptamente con la organización. ${ }^{43}$ Se considera entonces que la pluralidad de personas exigida en la organización (enunciada en párrafos anteriores) debe al menos llenar los niveles o modelos de organización planteados con la doctrina, para poder así llamarse organización propiamente y no una mera asociación delincuencial, que coinciden en su finalidad delictiva.

Establecer que la pluralidad puede constar de un binomio, sería una idea desacertada, puesto que dos individuos difícilmente pueden coordinar, ejecutar y consumar un crimen, al mismo tiempo, dado que se requiere de una estructura y elaboración rigurosa para cumplir la finalidad delictiva común. Además, no estaríamos frente a los modelos de organización analizados anteriormente y por ende, no puede considerarse como organización criminal. Precisamente en el concepto de organización y los modelos de configuración de la misma, hallamos la diferencia entre organización criminal y meras formas de autoría y participación (como lo analizamos en el capítulo anterior en cuanto a las problemáticas para definir el crimen organizado desde el derecho penal), sobretodo en la forma de organización

42 Sanchez García, Isabel. Criminalidad organizada, aspectos penales, procesales, adminsitrativos y policiales, Madrid, Dykinson, 2005. p.60. 
jerárquica o piramidal, que exige además de una pluralidad (conforme a lo que se dijo anteriormente, es necesario que sea más de dos) visualiza exigir una permanencia y estabilidad de los miembros dentro de la organización.

Este elemento temporal de la estructura organizacional, permite añadirle al término "organización" como característica fundamental del crimen organizado, la acepción de estable y duradera en el tiempo, toda vez que de no existir esta misma, no estamos hablando de organización sino de figuras de participación y complicidad. Esto lo ha considerado la doctrina como un elemento temporal, de índole connatural tanto al tipo penal de crimen organizado (para los países que así lo regulan), como para la organización misma, siendo requisito imprescindible para estimar a una agrupación delictiva como crimen organizado. ${ }^{44}$

\section{La finalidad lucrativa: ¿únicamente esta finalidad?}

La segunda característica que se enunció de las organizaciones criminales, es la finalidad lucrativa, que debe existir dentro de la misma. Al respecto, existe una interesante discusión en la doctrina, en cuanto considerar si, únicamente se habla debe finalidad lucrativa o también hay lugar a finalidades protagónicas sociales o políticas (adquiridas a través de medios violentos y no de los mecanismos democráticos constitucionalmente consagrados), como es el caso del terrorismo. Sin embargo, se analizarán ambos tópicos y se concluirá la viabilidad o no de que ambos concurran en la misma finalidad.

Del "animus lucrandi", se considera que las organizaciones persiguen obtener el mayor beneficio económico posible, obtenido a partir de la ejecución de delitos graves, aprovechando la mínima inversión realizada, toda vez que el material con que se emprende la organización criminal, es ilícito y las ganancias son mayores. ${ }^{45}$ Y es que tal situación, ya la hemos visto a través de la historia (cuando citábamos la piratería- para no citar concretamente ningún país en la actualidad-.), en donde el beneficio era mayor que la inversión en la obtención del mismo y existía además una repartición de ese beneficio ilícito. De tal modo, vale la pena aclarar, que el reparto de las utilidades, producto del alcance de esa finalidad ilícita, no es equitativo, sino por el contrario, siempre en organizaciones jerárquicas, el ingreso va a ser mayor para quien se encuentra en el primer nivel. 
En este punto, de acuerdo con la finalidad lucrativa, debe hacerse aclaración de otros fenómenos criminales, que comparten este tópico en común y es la criminalidad de empresa o empresarial. De este modo, Adrisola, y otros, citando a Antonio Laudati (Procurador Antimafia italiano), existen tres situaciones relacionadas con el crimen organizado y la empresa: 1. La empresa tomada como modelo de la organización criminal: se hace una copia exacta del modelo de administración y estructuración de la empresa. 2. La instrumentalización de la empresa: los miembros de la organización se valen de la constitución de la empresa para la comisión de delitos fines y 3 . la empresa, para legitimar activos que tienen su origen directo en una actividad delictiva (propio del lavado de activos o blanqueo de capitales). Con estas manifestaciones, surge el planteamiento de la responsabilidad penal para las personas jurídicas, cuestión de la cual no se ocupará este trabajo. De cualquier modo que se encuentre estructurada la organización, esta deberá ejecutar sus actividades con la finalidad de percibir un provecho o utilidad económica, lógicamente indebida, la cual no necesariamente debe estar representada en dinero (en la moneda propiamente dicha), sino en bienes fungibles que tengan un valor económico en el mercado y puedan constituir activos a nombre de la organización. ${ }^{46}$

Ahora bien, pueden existir otras finalidades, que no necesariamente excluyen la finalidad económica (necesaria), como por ejemplo los fines políticos de la organización. Según lo ha definido Zúñiga Rodríguez, es esto lo que precisamente distingue la criminalidad organizada de otras formas de criminalidad, cuyas ideologías son la promulgación de ideologías o fanatismos. ${ }^{47}$

Para ilustrar tal planteamiento, la autora señala que el terrorismo (como forma de organización, que busca fines más allá de los lucrativos) no puede considerarse criminalidad organizada, básicamente por cuatro aspectos, que se sintetizan a continuación: 1. Puede que el terrorismo requiera una estructura organizada, pero esta persigue una finalidad política, que no encaja dentro de la finalidad de lucro. 2. La criminalidad organizada actúa con sigilo y en secreto, el terrorismo busca más protagonismo. 3. La criminalidad organizada busca alianzas en el poder político, el terrorismo busca separarlo y 4 . La finalidad última, es la que limita un tipo de criminalidad y otra, más no la finalidad mediata. ${ }^{48}$

En este sentido, la doctrinante excluye otras finalidades de la criminalidad organizada (es importante resaltar, que la tesis mayoritaria en España, contempla

46 Adrisola, Gabriel, y otros. El crimen organizado: Desafios y perspectivas en el marco de la globalización, Buenos Aires, Ábaco De Rodolfo Depalma S.R.L, 2005.

47 Zuñiga Rodriguez, Laura. Criminalidad de empresa y criminalidad organizada, Lima, Jurista, 2013.

48 Ibídem p.613. 
que el terrorismo si es una forma de criminalidad organizada, sin embargo, existe quienes se separan de ese lineamiento), dejando de presente que únicamente debe ser una finalidad lucrativa.

Sin embargo, debe tenerse en cuenta, que el hecho no puede mirarse únicamente desde la óptica del terrorismo (pues hemos visto otras formas de organizaciones delictivas verdaderamente novedosas). De este modo, acudimos a otro fenómeno como es el de la corrupción política, que si bien actúa en secreto y en completo sigilo, a través del provecho económico, sus actores logran conseguir poco a poco el poder político y proclamarse como mandatarios en cualquiera de sus órdenes. En el caso señalado, la finalidad lucrativa y la finalidad política concurren (sin ser una más predominante que otra, puesto que al conseguir el poder político, igualmente aumentarán los ingresos del corrupto).

Entonces, si aceptamos que únicamente la finalidad debe ser lucrativa, un caso de un mandatario que llega al poder a través del fraude electoral en los comicios que aseguraron su elección, mostrando una estructura de poder que va desde el propio candidato hasta el jurado en los puestos de votación ¿no puede considerarse organización criminal, porque no persigue una finalidad lucrativa sino el puro poder político?

Se concluye entonces, concordando con Sanchez García, citando a Maltz:

(...) ambos $^{49}$ no son excluyentes y pueden coexistir, además de diferenciarse sólo hasta cierto punto en el plano teórico, toda vez que la concentración de un gran poder económico en una organización se transforma en poder político y, por otro lado, el poder político siempre implica poder económico. ${ }^{50}$

Ahora bien, esa finalidad (sea cual sea) no debe ser de algunos dentro de la organización, esa finalidad como se ha reiterado (en el apartado dedicado a la estructura de la organización), debe ser común, es decir, todos dentro de la organización deben mantener un interés directo en la consecución de ese fin, pues de otro modo no harían parte de la organización como figura estructurada, sino que serían meros partícipes de la misma.

\section{La comisión de crímenes}

Al analizar este punto debe entenderse que cuando se utiliza el vocablo crímenes, en un estricto sentido jurídico penal se hace referencia a injustos culpables cuyo

49 Hablando de los fines: lucrativo y de poder político.

50 Sanchez García, Isabel. Criminalidad organizada, aspectos penales, procesales, adminsitrativos y policiales, Madrid, Dykinson, 2005. p.41. 
grado de injusto conlleva a un mayor reproche y no sencillamente frente a delitos "menores". Y es válido entonces, hacer la distinción entre delito y crimen. Sobre ello ha discutido ampliamente la doctrina, sin embargo, para efectos del presente trabajo, se tendrá en cuenta, que la diferencia radical entre el uno y el otro (aunque sean casi equivalentes), radica en que el crimen, se manifiesta en consecuencias sociales de mayor magnitud y por tanto mayor reproche nacional e internacional, mientras que el delito es visto genéricamente.

Las conductas punibles, que realiza la organización son verdaderamente crímenes, pues su lesividad los hace meritorios de encajar dentro de esta categoría. La gravedad de estas conductas es determinada por la importancia de los bienes jurídicos que se vulneran y la potencialidad del ataque a los mismos. ${ }^{51}$ Como ya se ha establecido, la organización se constituye con una finalidad, es este ingrediente subjetivo que mantiene a la organización en el tiempo y funcionando de manera estructurada, así hasta conseguirla una y otra vez. Por ende, la organización no se constituye como tal para cometer delitos, sino por el contrario el delito guarda una relación teleológica directa con el fin perseguido.

Los crímenes cometidos por las organizaciones al margen de la ley, si bien son un medio en sí mismo, van atados a circunstancias modales, las cuales aseguran con mayor precisión la obtención de finalidad ilícita, ejemplo de ello es la violencia e intimidación. Así, el crimen organizado, encarnado en las organizaciones criminales propiamente, lo que busca no es la comisión de delitos, sino una finalidad especifica con el mayor número de ganancia posible (materialmente el dinero; de otro modo, curules, asignaciones políticas y así el poder).

En este punto, debe retomarse la discusión que se había planteado en la construcción del concepto del crimen organizado, desde la óptica del derecho penal según la cual, las realidades sociales (y es por ese motivo que precisamente la criminología nos ayuda a construir con mayor exactitud el concepto buscado) que vive cada nación en concreto, pues lo que aquí puede ser gravoso, en otro país puede que lo sea en menor grado y por ende los crímenes a los que se dedica a la organización criminal, no constituyen la misma significancia.

Amén de lo anterior, es necesario hacer un recorrido por otras legislaciones y analizar cómo han planteado el crimen organizado y cuáles son los medios punibles (o bien, conductas punibles, que utilizan como medios) para la consecución de su fin primario.

Es pertinente, en este punto, señalar el concepto de crimen organizado al cual se ha llegado (basándose en la historia, la doctrina y la crítica de la misma) y es que,

51 Ibídem, p.40. 
este consiste en la agrupación de más de dos personas de manera estructurada, en su mayoría jerarquizada, prolongándose en determinado espacio de tiempo, con una finalidad económica o política común, valiéndose de la comisión de crímenes para conseguirla.

\section{Latinoamérica y crimen organizado}

Según amnistía internacional, en su informe anual (2016), dentro de los cuatro países más violentos de América, se ubican: Brasil, México, Colombia y Venezuela. Mientras, que otras instituciones investigativas, como La revista Insigth Crime, especializada en crimen organizado en las Américas, incluye a El Salvador como "el país más violento del planeta", en su edición del 13 de enero (2015). ${ }^{52}$ Por ser un país fronterizo con una potencia mundial, México, puede considerarse como una ventana para la criminalidad organizada (de índole trasnacional), mediante el tráfico de mercancías, sustancias psicotrópicas y alucinógenas ilegales y migrantes. Según Benítez, la criminalidad organizada en México está basada en tres crímenes principalmente: tráfico de drogas, tráfico de armas y trata de personas. ${ }^{53}$

La criminalidad organizada en México, tiene tres modalidades de acción: evasión confrontación y corrupción. Esta última modalidad es la que nutre la transnacionalidad del crimen organizado mexicano y hace que este solidifique y haga más difícil su desarticulación (como ya lo habíamos anunciado anteriormente).

Considera la doctrina que en el país centroamericano, El crimen organizado se ha convertido en la principal amenaza al Estado y dentro de éste, las fronteras de México son los puntos más vulnerables ${ }^{54}$, manifestando que un país fronterizo hace más plausible la estructuración solida del crimen organizado. Aunado a ello, la corrupción, que según afirma el tratadista, si bien actúa con un aparente sigilo, es voz populi, dentro del territorio nacional. No se debe perder de vista lo dicho al inicio de este acápite, la violencia; tal situación constituye una amenaza para la sociedad civil y el estado mexicano, como un determinante para que las organizaciones criminales consigan el fin previsto..$^{55}$

Es por este motivo, que una de las políticas de estado para hacerle frente al crimen organizado en México fue la Ley Federal contra la delincuencia organizada,

52 Consultado en http://www.lapagina.com.sv/nacionales/103231/2015/01/21/El-Salvador-es-ya-elpais-mas-violento-del-mundo. Consultado el 8/9/16.

53 Benitez, Raul, Georgina Sánchez, Luis Guillermo Solis, Antonio Rangel, y Fernando Rospigliosi. Crimen organizado en América Latina y El Caribe, Santiago de Chile, Catalonia, 2008. p.175.

54 Ibídem, p.193.

55 Ibídem, p.32. 
promulgada en 1996, pero con una reciente reforma del 16 de junio de 2016, que permite una mayor regulación de este fenómeno.

Según plantea el instrumento legal, en su artículo 2, el crimen organizado se entenderá como:

Artículo 20.- Cuando tres o más personas se organicen de hecho para realizar, en forma permanente o reiterada, conductas que por sí o unidas a otras, tienen como fin o resultado cometer alguno o algunos de los delitos siguientes, serán sancionadas por ese solo hecho, como miembros de la delincuencia organizada (...) Se puede concluir entonces, que en México, la criminalidad organizada posee un concepto definido y delimitado, planteando una sanción penal independiente a aquella que el delito (como medio) plantea en su parte especial, haciendo más severo el castigo y procesamiento de este delito.

En Brasil por ejemplo, el crimen organizado, versa más sobre el uso de violencia, el dominio de territorios y uso de armas de fuego. Sin embargo, aunque desde los años 70 (Consistente en la explotación de una lotería popular: Jogo do Bicho. Esta actividad en su momento fue tolerada por el Estado y considera da una contravención.), se considere existe proliferación del crimen organizado, no existe una tipificación penal de crimen organizado como delito, sino por el contrario, este está subsumido en los delitos de susceptible comisión por parte de organizaciones criminales. ${ }^{56}$

\section{La realidad en Colombia}

Es necesario aclarar que en Colombia no hay una regulación alguna sancionatoria del crimen organizado como tipo penal autónomo (con dicha denominación típica, ni los elementos propios de la delincuencia organizada, analizados con anterioridad, detallados taxativamente). Es decir, si bien existen agravantes en determinadas conductas punibles que aumentan la pena atendiendo la participación criminal, no existe un tipo penal que defina plenamente y sancione las estructuras criminales organizadas como están definidas en los instrumentos internacionales.

Como anunciamos (en la dificultad de la construcción teórica del crimen organizado), en el territorio colombiano, más allá de lo que internacionalmente se ha publicado, la realidad interna del país, versa sobre otras modalidades de delitos susceptibles de organización criminal, los cuales van diluyendo el "protagonismo" mediático del terrorismo y el tráfico de drogas en el panorama delincuencial colombiano.

Debe señalarse además, que la historia colombiana en los últimos 50 años (para redondear una cifra), ha estado enmarcado por un conjunto de actos crueles 
y violentos, que sin duda son circunstancias modales utilizadas por la criminalidad organizada colombiana para lograr el éxito en el tráfico de drogas o conseguir el poder. Sumado a ello, los esfuerzos que ha realizado el estado colombiano (que siguen siendo insuficientes), en materia de extradición, no han hecho cesar conductas de organizaciones criminales trasnacionales, ni tampoco erradicar plenamente la violencia en el país. El inminente "pos conflicto" o bien, sino se tiene certeza del mismo "pos acuerdo de paz" colombiano, desata un fenómeno en la criminalidad organizada (que ya se viene presentando desde el fortalecimiento de los grupos subversivos) y es el surgimiento de poderes mafiosos, muy asimilables a modalidades de crimen organizado en espacios regionales y locales. ${ }^{57}$

Esta amenaza a la seguridad pública (y al estado mismo), surge a raíz de la transformación del paramilitarismo y su afán por preservar el poder en ciertos territorios del país, sin dejar de hacer uso de mecanismos violentos. Según el ex ministro de Justicia, Rafael Pardo Correa, esta situación sigue siendo crimen organizado notablemente. ${ }^{58}$

Según afirma Benítez, Sánchez, Solís, Rangel, \& Rospigliosi, el crimen organizado colombiano versa en cuatro actividades: tráfico de drogas, tráfico de armas, secuestro, extorsión y lavado de activos. ${ }^{59}$ Sorprende que se haya considerado el secuestro como un delito susceptible de comisión por parte organizaciones criminales colombianas, puesto en pocas ocasiones los medios internacionales lo citan, centrándose en el terrorismo, olvidando que el secuestro, ha sido uno de los medios violentos por excelencia, usado por los grupos subversivos para generar control social.

Sería errado señalar, que el Estado colombiano no ha empleado estrategias para frenar el crimen organizado, todo lo contrario, se han realizado esfuerzos en políticas criminales y profesionalización de la fuerza pública para erradicar el crimen organizado en el territorio. Ejemplo de esto, en el tráfico de drogas ha sido la ampliación y adiestramiento de los miembros de la Armada Nacional, en todos sus niveles (Guardacostas e Infantería de Marina) al igual que la FAC (Fuerza Aérea Colombiana), al igual que el empleo de estrategias de ataque a través de la Policía Nacional Colombiana, en el denominado "micro-tráfico" de drogas, de mayor comisión en comunidades periféricas y de escasos recursos.

57 Ibídem p.207.

58 Pardo Rueda, Rafael, Fin del paramilitarismo. ¿Es posible su desmonte?, Ediciones B, Bogotá, 2007, citado por Benitez, Sánchez, Solis, Rangel, \& Rospigliosi, 2008.

59 Benitez, Raul, Georgina Sánchez, Luis Guillermo Solis, Antonio Rangel, y Fernando Rospiglosi. Crimen organizado en América Latina y El Caribe, Santiago de Chile, Catalonia, 2008. p.209-213. 
De igual manera, en materia de extorsión y secuestro, tanto el Ejército como la Policía Nacional, cuentan con unidades tácticas especializadas en esta clase de delitos contra la libertad: GAULA (Grupo Antisecuestro y Antiextorsión), creadas bajo la Ley 282 de 1996 y cuya misión fundamental es llevar a cabo operaciones de rescate de secuestrados y desmantelamiento de bandas criminales causantes de los delitos que menoscaban la libertad personal de los colombianos ${ }^{60}$, trabajando en coordinación con la Fiscalía General de la Nación en investigación de estas conductas punibles.

Sin embargo, bien lo señalábamos citando a Zúñiga Rodríguez, en lo concerniente al concepto de crimen organizado, sino conocemos el concepto de crimen organizado, difícilmente sabríamos a qué nos estamos enfrentando y por ende los medios utilizados para enfrentarlo serían poco provechosos. ${ }^{61}$

\section{ONU y crimen organizado}

Antes de que existiera una construcción conceptual de crimen organizado, las organizaciones internacionales, han creado instrumentos internacionales para la lucha contra comportamientos delictivos de común comisión por agrupaciones delictivas. Es así como en el año de 1909, trece países constituyeron la llamada Comisión del Opio, que condujo a la Convención Internacional de Opio, firmada en la Haya en 1912, constituyéndose este en el primer acuerdo suscrito en materia de fiscalización de estupefacientes a titulo internacional. ${ }^{62}$

El tema de las drogas ilícitas desde sus inicios en la regulación internacional, ha sido una de las principales preocupaciones en materia de crimen organizado. Es así como se marcó un hito en 1988, cuando, la Organización de las Naciones Unidas, firma la denominada Convención de Viena, cuyo nombre correcto es "Convención de las Naciones Unidas contra el tráfico ilícito de Estupefacientes y Sustancias Sicotrópicas", el cual sirvió como sustento a los estados firmantes para emplear políticas de prevención y represión del tráfico de drogas en sus respectivos territorios.

Según afirma Linares Hamann, en la medida que otras modalidades delictivas, ejecutadas por organizaciones criminales, ganaban protagonismo y ocupan cifras a

60 Véase https://www.ejercito.mil.co/?idcategoria=71. Consultado el 8/9/16.

61 ZúÑIga Rodriguez, Laura. Criminalidad organizada y sistema de derecho penal, Granada, Comares, 2009.

62 Linares Hamann, Jorge. "Evolución de los instrumentos intrnacionales en la lucha contra el crimen organizado.» Criminanalidad: globalización y criminalidad, 2006: 90-97. 
nivel mundial, la ONU, buscaba crear instrumentos internacionales para la represión de los mismos, ejemplo de ello es cuando en 1989 y 1997, debido al auge de actividades terroristas, se firma respectivamente la Convención internacional contra el reclutamiento, la utilización, la financiación y el entrenamiento de mercenarios y el Convenio internacional para la represión de los atentados terroristas cometidos con bombas. ${ }^{63}$ En 1994, se celebra la Conferencia Mundial Interministerial sobre el Crimen Organizado Transnacional, (Nápoles 1994) a la cual asistieron 142 Estados que adoptaron por unanimidad la Declaración Política de Nápoles y el Plan de Acción Global contra el Crimen Transnacional Organizado, aprobados por la Asamblea General mediante Resolución 49/159. ${ }^{64}$

Sin embargo, fue hasta el año 2000 en la denominada Convención de Palermo, que se vieron materializados los esfuerzos por parte la Organización de las Naciones Unidas, por reprimir y definir la criminalidad organizada. Como se anunció en el introito de este trabajo, esta convención tiene una misión específica y de ella se deducen unas obligaciones de los Estados parte, que ratificaron dicha convención, entre las cuales se encuentran: la tipificación de delitos cometidos por organizaciones criminales; fortalecer los programas de prevención del crimen organizado a nivel nacional e internacional y cooperación internacional en la investigación de estas conductas. ${ }^{65}$

El logro de esta convención, fue crear un lenguaje universal respecto del concepto de crimen organizado, permitiendo a los Estados signatarios de la misma, crear políticas de Estado para la erradicación del mismo. Pero, iqué entiende la Convención de Palermo por Crimen Organizado?, esta convención, encarna este fenómeno en el de Grupo delictivo organizado y de tal suerte la define, en su artículo 2 literal a, de la siguiente manera:

Por "grupo delictivo organizado" se entenderá un grupo estructurado de tres o más personas que exista durante cierto tiempo y que actúe concertadamente con el propósito de cometer uno o más delitos graves o delitos tipificados con arreglo a la presente Convención con miras a obtener, directa o indirectamente, un beneficio económico u otro beneficio de orden material.

Así mismo, en su artículo 5, establece como deber de cada Estado parte, la penalización del grupo delictivo, cuando estos cometan conductas punibles graves,

63 Ibídem

64 Sanchez Garcia, Isabel, y Isidoro Blanco Cordero. "Principales instrumentos internacionales (de naciones unidas y la unión europea) relativos al crimen organizado", en Penal- Doctrina, s.f., pp. 3-14.

65 Linares Hamann, Jorge. «Evolución de los instrumentos intrnacionales en la lucha contra el crimen organizado.» Crimanalidad: globalización y criminalidad, 2006: 90-97. p.96. 
entrañen un beneficio económico y de igual forma a los integrantes de la misma, quienes dirijan, organicen, faciliten o asesoren la comisión de dichos delitos graves por parte de la organización. Vemos que, la definición construida anteriormente no es nada lejana a la que proporciona la Convención de Palermo y la cual muchos países han acogido en sus legislaciones, como es el caso de México y España.

\section{El silencio de la ley colombiana en la definición del crimen organizado}

Tomando como base el concepto otorgado por la Convención de Palermo y considerando nuevamente, que dicho instrumento fue ratificado por Colombia, desde hace más de diez años, no existe dentro del país latinoamericano, ningún instrumento jurídico penal que adopte esta definición. En materia procesal penal, la Ley 906 de 2004, hace referencia a los medios de investigación y las técnicas de investigación criminalística, orientadas a desmantelar estas organizaciones, como es el caso del artículo 241 de la mencionada ley, que establece el procedimiento para infiltrarse (un miembro de la policía judicial- organismo técnico investigativo adscrito a la Fiscalía General de la Nación-) en organizaciones criminales, pero pese a ello, no la define como tal.

La justicia penal colombiana, se ha centrado en la imputación del delito de concierto para delinquir, en los casos que atañen al crimen organizado. Este delito, si bien presenta un aumento gradual de las penas, cuando la concertación se refiera a determinadas conductas punibles, es un delito de mera asociación y desconoce los tópicos propios de la organización criminal.

Dicho esto, resulta imperioso identificar los elementos estructurales del tipo penal de concierto para delinquir:

"ARTICULO 340. CONCIERTO PARA DELINQUIR. Cuando varias personas se concierten con el fin de cometer delitos, cada una de ellas será penada, por esa sola conducta, con prisión de cuarenta y ocho (48) a ciento ocho (108) meses.

$<$ Inciso modificado por el artículo 19 de la Ley 1121 de 2006. El nuevo texto es el siguiente:> Cuando el concierto sea para cometer delitos de genocidio, desaparición forzada de personas, tortura, desplazamiento forzado, homicidio, terrorismo, tráfico de drogas tóxicas, estupefacientes o sustancias sicotrópicas, secuestro, secuestro extorsivo, extorsión, enriquecimiento ilícito, lavado de activos o testaferrato y conexos, o Financiamiento del Terrorismo y administración de recursos relacionados con actividades terroristas, la pena será de prisión de ocho (8) a dieciocho (18) años y multa de dos mil setecientos (2700) hasta treinta mil (30000) salarios mínimos legales mensuales vigentes. 
La pena privativa de la libertad se aumentará en la mitad para quienes organicen, fomenten, promuevan, dirijan, encabecen, constituyan o financien el concierto para delinquir.

$<$ Inciso adicionado por el artículo 12 de la Ley 1762 de 2015. El nuevo texto es el siguiente: > Cuando se tratare de concierto para la comisión de delitos de contrabando, contrabando de hidrocarburos o sus derivados, fraude aduanero, favorecimiento y facilitación del contrabando, favorecimiento de contrabando de hidrocarburos o sus derivados, la pena será de prisión de seis (6) a doce (12) años y multa de dos mil (2.000) hasta treinta mil (30.000) salarios mínimos legales mensuales vigentes.

Así las cosas, observamos que el tipo penal exige una pluralidad en el sujeto activo y una conducta básica de concertarse y la exigencia de un elemento subjetivo distinto del dolo y es, la finalidad de cometer delitos (no uno, sino varios). En tal sentido, no establece un catalogo puntual de delitos, sin embargo, agrava la pena el legislador cuando se refiere a determinados tipos penales como componentes del ingrediente subjetivo.

Se observa entonces, que, teniendo en cuenta los elementos analizados de la delincuencia organizada, este tipo penal carece de capacidad descriptiva para cobijar los presupuestos de la delincuencia organizada, tales como la estructura, la duración en el tiempo y la gravedad de las conductas (sin que ello indique agravación de la consecuencia jurídica)

Uno de los tópicos que desconoce fundamentalmente, es la de la organización estructurada (entendiendo la pluralidad mínima y la duración en el tiempo) y de tal suerte, no debería el Estado colombiano darle el tratamiento de un delito de mera asociación a grandes organizaciones criminales. Es por este motivo que acorde con Zúñiga Rodríguez, los delitos de asociación criminal, como es el caso del concierto para delinquir en Colombia, no son idóneos para hacer frente a la criminalidad organizada, dado que el delito de asociación, no comprende los diversos comportamientos susceptibles de sanción penal (por ser de mera actividad o mera conducta), cuestión que como ya vimos, si se ocupa el fenómeno de la organización criminal. ${ }^{66}$

Citando al Exviceministro de justicia de Colombia, Dr. Farid Benavides Vanegas, la problemática de Colombia, se centra en que no se ha empleado una política integral (a la luz de la Convención de Palermo), que ataque al crimen organizado como tal, sino que atacan problemas específicos en los que esta modalidad criminal toma partido.

66 Zuñiga Rodriguez, Laura. Criminalidad de empresa y criminalidad organizada, Lima, Jurista, 2013. p.654. 
Afirma el ex funcionario de este gabinete que:

En materia de lucha contra el crimen organizado, no se observaba ninguna política coherente dirigida a controlarlo, sino políticas parciales destinadas al control del narcotráfico o del secuestro, sin tener en cuenta la necesidad de una política integral contra esta actividad que involucrara a todas las instituciones del Estado. ${ }^{67}$

Así mismo, como se señaló en el capítulo inicial, Colombia padece otros flagelos producto del crimen organizado, que poco a poco van ganando terreno (e incrementando el hacinamiento carcelario existente) y es por ello necesario plantear un concepto nacional, de crimen organizado, tomando como base los tratados y convenios internacionales.

Ahora bien, aunque constitucionalmente, los jueces en sus providencias están sometidos al imperio de la ley (artículo 230 de la Constitución Política de Colombia), resulta importante analizar el concepto de la jurisprudencia al respecto de esta temática. Puesto, que si bien, no es una fuente de Derecho directa, es un criterio auxiliar e interpretativo para el operador de justicia.

En este sentido, la Corte Constitucional en Sentencia C- 334 el 13 de junio de 2013, al analizar la constitucionalidad de los agravantes del concierto para delinquir, estableció los elementos de la delincuencia organizada y como estos convergen con el tipo objetivo de concierto para delinquir, así como la evolución normativa que ha tenido este tipo penal, evidenciando de alguna forma un interés por relacionarlo con la delincuencia organizada.

De este modo establece la Corte como criterio para agravar la pena del concierto para delinquir (específicamente cuando el sujeto activo fuere miembro activo o retirado de las fuerzas de seguridad del Estado), la existencia del fenómeno criminal de la delincuencia organizada y el peligro que esta representa para la seguridad pública.

Así las cosas, el órgano plural en este proveído, citando a Sánchez García, establece que:

3.6.2. La criminalidad organizada tiene a su vez las siguientes características:

(i) la concertación de varias personas para la comisión de delitos, (ii) con cierta organización (iii) estabilidad y permanencia; (iv) está dirigida a la comisión de delitos graves; (v) adopta una estructura compleja y (vi) tiene

67 Benavides Vanegas, Farid. Control penal del crimen organizado en Colombia 1980-2014, FES- SEGURIDAD, 2015, pp. 6-27. 
por objeto el beneficio o poder. En este sentido, la criminalidad organizada constituye una empresa mundial que mueve miles de millones de dólares y que resulta una antítesis de la sociedad civil (...). (C-334 de 2013). ${ }^{68}$

Se evidencia entonces, que la Corte Constitucional, es consciente del concepto de criminalidad organizada, de sus elementos y de la peligrosidad de que dicho fenómeno representa para el Estado. En ese sentido, la Corte considera que el delito de concierto para delinquir, sustrae en si mismo el reproche a la delincuencia organizada. Esta postura la deja clara, cuando, citando a la Corte Suprema, establece:

El delito de concierto para delinquir, presupone la existencia de una organización, conformada por un grupo de personas que se han puesto de acuerdo o han convenido llevar a cabo un número plural de delitos y de este modo lesionar o poner en peligro indistintamente bienes jurídicos.

En consecuencia, lo esencial en el concierto para delinquir es la organización de una empresa criminal sin que sea necesario para su configuración alcanzar el cumplimiento de los fines criminales propuestos por la organización, por lo cual se consuma con el solo acuerdo, pues se trata de un delito de peligro contra la seguridad pública. En este sentido, el concierto para delinquir es un delito independiente y distinto de los delitos específicos que comete la organización, los cuales podrán ser sancionados de manera autónoma. ${ }^{69}$

Se observa entonces que la Corte Constitucional equipara la organización criminal a la concertación delictiva, para efectos de la adecuación del tipo penal de concierto, estableciendo los elementos de pluralidad, finalidad delictiva y organización.

Por otra parte, la Sala de Casación Penal de la Corte Suprema de Justicia, en sentencia radicada bajo el número SP 2772-2018 del 11 de julio de 2018, cuyo Magistrado Ponente fuere Luis Antonio Hernández Barbosa; permite aclarar la diferencia entre concierto para delinquir y coautoría, al analizar la planeación y ejecución de conductas delictivas de homicidio agravado (entre otras) por parte de miembros de las fuerzas militares.

En esta providencia la Sala de Casación Penal de la Corte, analiza si efectivamente existió violación directa a la ley sustancial, por cuanto (según alega el casacionista), se trata de una mera coautoría material impropia y no de un concierto para delinquir

68 Sanchez García, Isabel. Criminalidad organizada, aspectos penales, procesales, adminsitrativos y policiales, Madrid, Dykinson, 2005. 
propiamente. En consecuencia, de ello, la Sala detalla los elementos del concierto y los usa para determinar si efectivamente el caso concreto estos se configuraron.

De igual manera y conforme a los precitados postulados de la Corte Constitucional, la Sala de Casación pena, considera subsumidos los presupuestos de la delincuencia organizada en el tipo penal de concierto para delinquir. Deja tan marcada su postura la Sala, que estos mismos argumentos constituyen la esencia diferenciadora del concierto con la coautoría impropia, esto se evidencia cuando la Sala expresa:

A diferencia del instituto de la coautoría material en el que la intervención plural de individuos es ocasional y se circunscribe a acordar la comisión de delitos determinados y específicos, en el concierto para delinquir a pesar de también requerirse de varias personas es necesario que la organización tenga vocación de permanencia en el objetivo de cometer delitos indeterminados, aunque se conozca su especie. ${ }^{70}$

Y continua la Sala:

En suma, el delito de concierto para delinquir requiere, primero: Un acuerdo de voluntades entre varias personas. Segundo: Una organización que tenga como propósito la comisión de delitos indeterminados, aunque pueden ser determinables en su especie. Tercero: vocación de permanencia y durabilidad de la empresa acordada y cuarto que la expectativa de realizaci6n de las actividades propuestas permita suponer fundadamente que se pone en peligro la seguridad. ${ }^{71}$

Así las cosas, tanto la Corte Constitucional, como la Sala Penal de la Corte Suprema de Justicia, coinciden en que los elementos constitutivos de la delincuencia organizada, se encuentran subsumidos en el tipo penal de concierto para delinquir. Criterio este, que es únicamente jurisprudencial y que no necesariamente configura una política criminal, racional y coherente con el fenómeno criminal.

Sin embargo, los anteriores son (como se dijo) criterios auxiliares e interpretativos, que bien podrían emplearse a la hora de enfrentar judicialmente esta conducta, sin que exista pronunciamiento legislativo alguno que constituya una política criminal (encaminada a la tipificación del delito), sin lugar a equívocos 0 vacíos normativos.

70 Sentencia. SP 2772-2018 (Corte Suprema de Justicia, Sala de Casación Penal., 11 de julio de 2018). p.13.

71 Ibídem, p.18. 


\section{Conclusiones}

Como se ha evidenciado en este trabajo, no es sencilla la construcción del concepto de crimen organizado, de tal forma que debe partirse de bases históricas y de la realidad social de cada nación. Pese a eso, existen esfuerzos internacionales encaminados a aportar una construcción teórica completa de Criminalidad Organizada, ejemplo de ello es la Convención de Palermo de 2000, ratificada por 147 Estados y ratificada por 115 de ellos.

Aunque exista un pronunciamiento internacional, el cual Colombia ha venido adoptando, aun el Estado no se ha pronunciado respecto del concepto de crimen organizado y ha sometido a sus funcionarios judiciales a aplicar el tipo penal de concierto para delinquir, en todo tipo de organizaciones, sin importar si estas trascienden las esferas de lo nacional, su permanencia en el tiempo y la complejidad de su estructura.

De igual forma no es excusa, que la realidad de cada país sea distinta, para eludir la construcción conceptual del crimen organizado, cuando Colombia, ya ha ratificado un instrumento internacional (y ha cumplido parcialmente, puesto que ha obtenido logros en materia de cooperación internacional; investigación de criminalidad organizada y aumento de las penas) que le permite establecer bases conceptuales.

No puede desconocerse que la jurisprudencia de las altas Cortes ha guiado de alguna forma el sentir del sistema judicial frente a la delincuencia organizada, sin embargo, no resulta ello suficiente, puesto que se esta ampliando cada vez mas el radio de aplicabilidad del concierto para delinquir, que como ya se dijo cuando se citó a Zúñiga Rodríguez, delitos de mera asociación como el concierto, desconocen elementos estructurales propios de la delincuencia organizada.

Resulta curioso, que un país el cual tiene tantas potencialidades en materia agrícola y cultural, sea más conocido internacionalmente por el terrorismo y el tráfico de drogas y aun peor, que estos mismos no se encuentren consagrados legalmente en materia de crimen organizado.

\section{Bibliografía}

Adrisola, Gabriel, y otros. El crimen organizado: Desafios y perspectivas en el marco de la globalización, Buenos Aires, Ábaco De Rodolfo Depalma S.R.L, 2005. BARATT. s.f.

Benavides Vanegas, Farid. Control penal del crimen organizado en Colombia 1980-2014, FES- SEGURIDAD, 2015, pp. 6-27. 
Benitez, Raul, Georgina Sánchez, Luis Guillermo Solis, Antonio Rangel, y Fernando Rospiglosi.

Crimen organizado en América Latina y El Caribe, Santiago de Chile, Catalonia, 2008

Bermudez Bermudez, Arturo. Piratas En Santa Marta, Santa Marta, Kimpres, 1991.

Choclán Montalvo, José Antonio. La organización criminal, tratamiento penal y procesal, Madrid, Dykinson, 2000.

Fabián Sain, Marcelo, y Nicolas Rodríguez Games. Tendencias y desafíos del crimen organizado en latinoamerica, Buenos Aires, Universidad Metropolitana para la Educación y el Trabajo UMET, 2015.

Gosse, Philı. Historia de la pirateria, Febrero de 2013. https://doscenturiasymasalla. files.wordpress.com/2013/02/32730422-philip-gosse-historia-de-la-pirateria.pdf. Hernandez Chavéz, Mabel , y Jorge Linares Hamann. "Tráfico de especies silvestres como empresa del crimen organizado", en Revista Criminalidad, Lo local y el Crimen Organizado, 2006, pp. 338-348.

LinaRes Hamann, JoRGE. "EVOLUCIÓN DE LOS INSTRUMENTOS INTRNACIONALES EN LA LUCHA CONTRA EL CRIMEN ORGANIZADO.» Crimanalidad: Globalización y Criminalidad, 2006: 90-97.

Poveda Criado, Miguel Angel. Terrorismo global y crimen organizado, Madrid, Fragua, 2015.

Rivera Clavería, Julio. "Galilelo.edu", enero de 2011. http://www.galileo.edu/ies/ files/2011/04/EL _ CRIMEN_ ORGANIZADO-IES.pdf.

Sanchez García, Isabel. Criminalidad organizada, aspectos penales, procesales, adminsitrativos y policiales, Madrid, Dykinson, 2005.

Sanchez Garcia, Isabel, y Isidoro Blanco Cordero. "Principales instrumentos internacionales (de naciones unidas y la unión europea) relativos al crimen organizado", en PenalDoctrina, s.f., pp. 3-14.

Sentencia. SP 2772-2018 (Corte Suprema de Justicia, Sala de Casación Penal., 11 de julio de 2018).

Sentencia. C-334 (Corte Constitucional, 13 de junio de 2013).

Velásouez Velásouez, Fernando. Manual de derecho penal parte general, Bogotá, Andres Morales, 2014.

ZuñIga Rodriguez, Laura. Criminalidad de empresa y criminalidad organizada, Lima, Jurista, 2013.

ZúñIga Rodriguez, LaURa. Criminalidad organizada y sistema de derecho penal, Granada, Comares, 2009 